Relations industrielles

Industrial Relations

\title{
The CCCL Founds a Workers' College
}

\section{Fernand Jolicoeur}

Volume 7, numéro 4, septembre 1952

URI : https://id.erudit.org/iderudit/1023039ar

DOI : https://doi.org/10.7202/1023039ar

Aller au sommaire du numéro

\section{Éditeur(s)}

Département des relations industrielles de l’Université Laval

\section{ISSN}

0034-379X (imprimé)

1703-8138 (numérique)

Découvrir la revue

Citer ce document

Jolicoeur, F. (1952). The CCCL Founds a Workers' College. Relations industrielles / Industrial Relations, 7(4), 355-356. https://doi.org/10.7202/1023039ar

Tous droits réservés @ Département des relations industrielles de l’Université Laval, 1952
Ce document est protégé par la loi sur le droit d'auteur. L'utilisation des services d'Érudit (y compris la reproduction) est assujettie à sa politique d'utilisation que vous pouvez consulter en ligne.

https://apropos.erudit.org/fr/usagers/politique-dutilisation/ 


\section{INFORMATION}

\section{THE C.C.C.L. FOUNDS A WORKERS' COLLEGE}

The C.C.C.L. will inaugurate at Quebec, the coming November, a workers' College in which the courses will last four weeks. It is the first time in the country that an experiment in labour education as long as this will be tried. Up to now. the different union movement's have held repeated intensive sessions of three o: four days, even as long as ten days. But it was not possible, in such a short period to give a formation at the same time broad enough and detailed enough to meet the multiple needs of the militant workers. Can it be done in a month? We realize that this will still be an illusion. But we want to make a further step towards the establishment of a permanent school of unionism where we could prepare more labour leaders.

\section{Evolution of the Canadian Labour Movement}

The Canadian labour movement has now come of age. The two world wars and the economic depression, as well as the upset situation which followed these cvents and which seems as though it would continue for a long time yet, has put unionism to the test and has made of it a basic element in the radical evolution of social and economic life which is going on under our eyes. By its ascension, it has been induced to make its aims more clear and take up well defined positions.

It has necessitated a more and more active participation of the working class in the life of the enterprise, of the profession and of the nation. It has clearly indicated that this participation must increase up to a frank and free cooperation with the other social groups. It has never felt more than to-day the urgent need to find in the ranks of the workers themselves, the leaders capable of conducting it towards its true destiny which is not only the demands in regard to more human labour conditions but the reform of the structures itself of society.

\section{Necessity of a College}

As the workers become conscious of the new responsibilities of their class in a world that becomes more and more industrialized, they insist with reason that their movement furnish them the opportunity to acquire an economic and social formation which will permit' them to cope with their problems and to fill the multiple functions that may be entrusted to them. We can no longer be content with dispensing only the necessary elements to an immediate union action. We must open horizons as wide as the world and give the taste of a culture appropriate to humanity. A workers' college which merits the name must now be a great school which takes as much care to build up its curricula as to choose its professors and to select its pupils.

\section{Course of Studies}

The principal courses on the programme of this workers' college of the C.C.C.L. will be on social, economic and union history, on political economy as it exists in Canada, on the Federal and Provincial labour legislation, on union techniques, in the Church's social doctrine and on the declaration of principles of the C.C.C.L.

But a good many hours will also be given to more practical courses, such as - methods of worker education, propaganda and publicity, meeting procedures and 
public speaking. We wish not only to form men capable of finding solutions to their economic or social problems, but also monitors to lead their fellow-workers. The best workers' education that can be given is that by the workers themselves.

\section{Method of Teaching}

The method that will be used will take into account the subjects under study, the workers themselves as well as the end that it is desired to attain.

The subjecis under study are practical subjects, human problems which require much more personal and common thought than they require technical or theoretica! expositions. Workers are adults already at grips with the questions that it is desired to help them solve. We propose as aim to show at once the working class the rôle that it must play in society and to help it play this rôle immediately.

One method must, therefore, be an active one. It must permit everyone to express his own difficulties or his own way of looking at things. It must accustom the worker to discuss and look for and find himself the answers. Each course explained will be followed by a discussion. Some courses will include practical work carried out by the pupils, for example, arguments for an increase in wages before an arbitration council; editing of a newspaper for the pupils; make up of circulars and posters, etc.

The courses will be given by professors of Laval University, specialists in the questions on the programme; officers and permanent employees of the C.C.C.L. The professors will be at' the disposition of the pupils between courses which will be given in the Catholic Syndicates building where the C.C.C.L. has its head office. The programme will cover the four consecutive weeks of the month of November, from Monday morning to Friday night. During the week-ends, the pupils will return home from Saturday morning to Monday morning. A programme of recreation is provided to fill the spare time after the courses and the Tuesday and Thursday evenings which will be left free.

This Workers' College is especially for those who have already acquired a minimum of union knowledge, by study or practice, either, in following study groups, sessions of the regional school for workers action, etc., or in filling a post of officer, business agent, organizer, department delegate, service representative. This elementary preparation is necessary in order to follow with advantage the more advanced courses which will be given.

\section{EXPensive and Necessary Task}

Ii will be expensive to compensate the wage of about thirty workers who will leave the factory for a whole month and pay their room, board. and the cost of the course for the same period. But all the organizations affiliated with the C.C.C.L. are ready to make the sacrifices that such a heavy burden will impose upon them in order to assure unionism of a future that will be worth the efforts that they are making to-day. As a movement of Catholic inspiration, we owe it to ourselves more than others to form fool-proof leaders who could direct the working class in its struggle for liberty as well as for the true peace of all society. 